\title{
TRACER STUDY: KETERSERAPAN DAN KEPUASAN PENGGUNA ALUMNI PGMI UNWAHAS LULUSAN TAHUN 2015, 2016 DAN 2017
}

\author{
Ma'as Shobirin, Ali Imron, Ummu Jauharin Farda \\ Prodi Pendidikan Guru Madrasah Ibtidaiyah, Fakultas Agama Islam \\ Universitas Wahid Hasyim Semarang \\ ma’as.shobirin@unwahas.ac.id
}

\begin{abstract}
Abstrak
Penelitian ini berusaha melakukan penelusuran terhadap alumni atau biasa disebut dengan tracer study PGMI paska lulus tahun 2015, 2016 dan 2017. Tracer study merupakan bagian penting dari evaluasi program studi untuk mengetahui sejauh mana keterserapan alumni di dunia kerja. Tidak hanya itu, penelitian ini juga berusaha mencari kepuasan pengguna alumni PGMI FAI Universitas Wahid Hasyim Semarang. Berdasarkan penelitian yang sudah dilakukan dapat disimpulkan bahwa pekerjaan alumni setelah lulus dari kuliah sebagian besar relevan dengan kompetensinya, yaitu guru. Sebanyak 84 responden bekerja sebagai guru, 8 bekerja di sektor lain, 4 responden menikah, dan 8 responden melanjutkan studi S2. Dengan demikian dapat disimpulkan bahwa alumni PGMI sangat siap bekerja dengan kompetensi yang dimilikinya. Lulusan PGMI memiliki masa tunggu yang relatif baik, yakni di bawah 6 bulan, bahkan 58 responden bekerja dengan masa tunggu di bawah 3 bulan. Hal ini dikarenakan para responden banyak yang sudah ikut membantu ekstra kurikuler seperti pramuka, seni, atau ekstra lain sehingga mereka sudah diminta ikut mengajar bahkan sebelum lulus. Kompetensi lulusan yang sangat menunjang kinerja alumni dengan nilai sangat baik terbanyak adalah integritas yang berupa kejujuran, sikap, dan tanggung jawab alumni dalam bekerja. Kemudian komunikasi alumni juga dinilai sangat baik.
\end{abstract}

Kata Kunci: Tracer Study, Kepuasan Customer, Alumni PGMI FAI Universitas Wahid Hasyim Semarang

Abstract

This study try to search alumni or usually called tracer study PGMI after graduated in 2015, 2016, and 2017. Tracer study is an important thing from study program evaluation which to know how far the absorbtion of alumni in (working market). Not only for that reason, this study also search the user satisfaction of alumni FAI Universitas Wahid Hasyim Semarang. Based on previous study we can conclude that alumni's occupation after graduate from their study is relevant to their competencies, that is teacher. 84 respondents work as teacher, 8 respondents work in other sector, 4 respondents are married and 8 respondents continue their study on higher tevel. Therefore we can conclude that alumni of PGMI Unwahas are ready to work with their competencies. The alumni of PGMI is having relative good waiting 
period, it is under 6 months. Even 58 respondents are under 3 months, it is because many respondents already take a part in helping extracurriculer such as boyscout, art or another extra, so they are asked to teach even they not graduate yet. The competencies of alumnus are support their performance with the most and best values are intergrity such as honesty, attitude and alumnus responsibility in working. They also comminicate in a good way too.

Keywords: tracer study, user satisfaction, alumni of PGMI FAI Universitas Wahid Hasyim Semarang

\section{A. PENDAHULUAN}

Pendidikan tinggi merupakan kelanjutan pendidikan menengah yang diselenggarakan untuk menyiapkan peserta didik menjadi anggota masyarakat yang memiliki kompetensi akademik dan profesional yang dapat menerapkan, mengembangkan dan menciptakan ilmu pengetahuan, teknologi dan kesenian. Di samping itu, sebagai lembaga berbadan hukum pendidikan tinggi bertujuan untuk mendukung pembangunan masyarakat madani yang demokratis dengan berperan sebagai kekuatan moral yang mandiri, serta untuk mencapai keunggulan kompetetif melalui penerapan prinsip pengelolaan sumberdaya sesuai dengan asas pengelolaan yang professional ${ }^{1}$. Untuk dapat mencapai kompetensi seperti dalam statuta tersebut maka Universitas Wahid Hasyim Semarang dituntut untuk mampu melaksanakan Tri Dharma perguruan tinggi secara optimal, yakni bidang pendidikan, bidang penelitian dan bidang pengabdian masyarakat. Secara khusus Universitas Wahid Hasyim Semarang menjabarkannya diantaranya melalui tri etika kampus, yakni diniyah, ilmiah dan ukhuwah.

Diniyah artinya seluruh civitas akademika Universitas Wahid Hasyim Semarang diharapkan menguasai materi-materi keagamaan sehingga dapat diamalkan dalam kehidupan sehari-hari. Ilmiah berarti meskipun masyarakat Universitas Wahid Hasyim Semarang itu agamis tidak mengesampingkan aspek-

\footnotetext{
${ }^{1}$ Lihat Pasal 2 Peraturan Pemerintah Nomor 60 tahun 1999 tentang Perguruan Tinggi. Lihat juga Pasal 3 Peraturan Pemerintah Nomor 61 tahun 1999 tentang Penetapan Perguruan Tinggi Negeri
}

72 MAGISTRA - Volume 10 Nomor 1 Juni 2019 
aspek rasional untuk mendukung keyakinan beragama yang telah dipegangi. Ukhuwah berarti output Universitas Wahid Hasyim Semarang menjadikan orang yang agamawan dan ahli agama, sekaligus menjunjung tinggi rasa persaudaraan baik persaudaraan Islam (ukhuwah Islamiyah), persaudaraan sebangsa (ukhuwah wathaniyah) maupun persaudaraan kemanusiaan (ukhuwah basyariyah). Dari tri etika kampus ini diharapkan para alumni Universitas Wahid Hasyim Semarang bisa melayani masyarakat di bidang sosial keagamaan sesuai dengan kebutuhan. Sehubungan dengan hal tersebut program Studi Pendidikan Guru Madrasah Ibtidaiyah (PGMI) Fakultas Agama Islam (FAI) sebagai salah satu unit pelaksana dari Universitas Wahid Hasyim Semarang yang terfokus pada pendidikan mempunyai misi untuk mencetak para calon guru kelas Madrasah Ibtidaiyah yang memiliki empat kompetensi, yakni kompetensi paedagogik, kompetensi kepribadian, kompetensi professional dan kompetensi sosial. ${ }^{2} \mathrm{Hal}$ ini dimaksudkan untuk melayani kebutuhan akan guru kelas pada tingkat pendidikan dasar yang bernaung di bawah Kementerian Agama. Kemudian untuk memenuhi kebutuhan ini.

Program Studi PGMI telah membekali mahasiswa dengan seperangkat ilmu yang berkaitan dengan kebutuhan guru kelas di pendidikan dasar. Di samping itu, mahasiswa juga dibekali Ilmu Agama Islam sebagai penguat keimanan serta ciri khas pendidikan tinggi Islam, Ilmu Bahasa, Ilmu Keguruan dan Ilmu Kependidikan. Secara umum Program Studi PGMI bertujuan untuk mendidik mahasiswa yang dipersiapkan untuk menjadi guru kelas yang mampu

2 Yang dimaksud dengan kompetensi paedagogik adalah kemampuan mengelola pembelajaran peserta didik. Kompetensi kepribadian adalah kemampuan memiliki kepribadian yang mantap, berakhlak, arif dan berwibawa serta menjadi teladan bagi peserta didik. Kompetensi professional adalah kemampuan penguasaan materi pelajaran secara luas dan mendalam. Dan kompetensi sosial adalah kemampuan guru untuk berkomunikasi dan berinteraksi secara efektif dan efesien dengan peserta didik, sesama guru, orang tua/wali peserta didik dan masyarakat sekitar. Lihat Undang-undang Republik Indonesia Nomor 14 Tahun 2005 Tentang Guru dan Dosen, Jakarata: Depdiknas RI, 2006, hlm 69 
menguasai materi-materi kelas tinggi dan model tematik ${ }^{3}$ maupun metodologi pembelajarannya.

Secara umum materi-materi guru kelas telah terangkum dalam empat kategori, yakni 1) materi-materi yang berhubungan ilmu sosial yang direprsentasikan dengan mata kuliah IPS pada Pendidikan Dasar, 2) materimateri yang berhubungan dengan sains yang direpresentasikan dengan mata kuliah IPA pada Pendidikan Dasar, 3) materi-materi yang berhubungan dengan civic education 4) materi-materi yang berhubungan dengan Bahasa Indonesia, 5) materi-materi yang berhubungan dengan dasar-dasar matematika. ${ }^{4}$ Sedangkan untuk keahlian dalam metodologi pembelajaran, mahasiswa program studi Pendidikan Guru Madrasah Ibtidaiyah (PGMI) dibekali materi-materi yang berhubungan dengan ilmu keguruan dan kependidikan dengan tujuan setelah mereka menjadi guru nanti menunjukkan performance sebagai pendidik yang mempunyai kompetensi sebagaimana yang dipersyaratkan Undang-undang. Artinya para lulusan PGMI mampu 1) membuat perencanaan pembelajaran (lesson plan) materi yang akan disampaikan dengan segala langkah-langkahnya, 2) melaksanakan proses pembelajaran (learning process) dengan menggunakan metode, strategi, pendekatan, media dan alat bantu pembelajaran (learning aid) yang tepat, 3) mampu melakukan pengelolaan kelas (classroom management) dan 4) melaksanakan penilaian (assesement) sebagai ukuran keberhasilan atas dirinya sebagai guru dalam proses pembelajaran di kelas. Dengan bahasa lain, mereka diharapkan mampu melakukan pembelajaran yang efektif ${ }^{5}$ dalam praktik

\footnotetext{
${ }^{3}$ Untuk Kurikulum 2013, model pemebelajaran di Sekolah Dasar dan Madrasah Ibtidaiyah menggunakan tematik terpadu. Lihat Permendikbud Nomor 32 tahun 2013 tentang perubahan Standar Proses Pembelajaran

${ }^{4}$ Lihat Buku Panduan Akademik IAIN Walisongo Tahun 2014, Semarang: IAIN Walisongo, 2014.

${ }^{5}$ Pembelajaran efektif adalah pembelajaran yang dapat merangkum empat unsur terpenting, yakni : Planning, Learning Process, Classroom Management dan Assesement. Lihat Booby de Potter, Quantum Teaching, Birmingham: Routladge Press, 2000, hlm 342.
} 
yang sesungguhnya dengan mempertimbangkan gaya belajar peserta $\operatorname{didik}^{6}$.

Dengan dibekali kemampuan penguasaan materi dan kemampuan mengaplikasikan metodologi sebagaimana disebutkan di atas, mereka diharapkan siap pakai untuk menjadi guru yang mengajarkan mata pelajaran-mata pelajaran di kelas dan mengajarkan tematik terpadu di Madrasah Ibtidaiyah bahkan di Sekolah Dasar sebagai masyarakat pengguna. Seperti diketahui bahwa masyarakat pengguna alumni program studi PGMI adalah lembaga pendidikan sekolah dan madrasah sebagai guru kelas. Lembaga pendidikan madrasah termasuk MI- mempunyai karakteristik yang menarik, madrasah didirikan untuk memadukan keunggulan pesantren dan sekolah di samping untuk menghilangkan kelemahan di antara keduanya ${ }^{7}$. Jadi bisa dikatakan madrasah adalah sekolah yang plus, perpaduan antara sekolah yang banyak pelajaran umumnya dengan pesantren yang menekankan pelajaran agamanya. Keunggulan tersebut tentunya harus diperkuat dengan melahirkan calon pendidik MI yang berkualitas dan unggul pula. Dengan demikian jelas sekali bahwa alumni program studi PGMI harus berkualitas.

Pada kenyataannya alumni program studi PGMI tidak hanya sebagai guru kelas. Bisa saja mereka mengajar mata pelajaran seperti PAI bahkan bahasa Inggris dalam kurikulum muatan lokal. Kasus seperti ini banyak terjadi sehingga mengakibatkan mismatched-teacher (guru mengajar tidak sesuai dengan bidang keahliannya). Maka wajar kalau menghasilkan siswa-siswa yang tidak qualified dan kurang sesuai dengan standar kompetensi yang dipersyaratkan. Di samping itu, perlu dilihat dari kaca mata supply and demand theory di mana teori ini

\footnotetext{
${ }^{6}$ Gaya belajar adalah cara konsisten yang dilakukan oleh seorang siswa dalam menangkap stimulus atau informasi, cara mengingat, berfikir dan memecahkan soal. Tidak semua orang mengikuti cara yang sama. Masing-masing menunjukkan perbedaan, namun para peneliti dapat menggolonggolongkannya gaya belajar ini berkaitan erat dengan pribadi seseorang, yang tentu dipengaruhi oleh pendidikan dan riwayat perkembangannya. Lihat Nasution, Berbagai Pendekatan dalam Proses Belajar dan Mengajar, Jakarta: Bumi Aksara, 2003, hlm 94. 2008, hlm 77 .

7 Sutrisno, Pendidikan Islam Yang Menghidupkan, Cet II , Yogyakarta: Kota Kembang,
} 
mengatakan bahwa antara kebutuhan guru kelas dan alumni haruslah berimbang. Apabila alumni program studi PGMI terlalu banyak sementara kebutuhan akan guru kelas terbatas maka terjadi penumpukan guru kelas di lembaga madrasah atau sekolah yang akhirnya mereka mengampu mata pelajaran yang tidak diharapkan (mismatched teacher). Sebaliknya ketika kebutuhan akan guru kelas meningkat sementara alumni program studi PGMI terbatas maka yang akan terjadi adalah banyak lembaga madrasah atau sekolah mengambil jalan pintas dengan cara mengambil para alumni pendidikan tinggi yang tidak sesuai latar belakang pendidikannya ataupun bahkan under-qualified (di bawah kualifikasi yang persyaratkan) sebagai guru kelas.

Perguruan tinggi sebagai sebuah lembaga pendidikan tingkat tinggi yang menghasilkan lulusan (SDM) siap kerja, dituntut menjunjung tinggi profesionalisme serta senantiasa menjaga dan meningkatkan kualitas pendidikannya. Kualitas pendidikan tersebut meliputi kualitas tenaga pendidik, proses pembelajaran, dan lulusan yang dihasilkan. Dalam konteks sosial, kualitas lulusan paling mudah dirasakan manfaatnya dan diamati masyarakat. Hal ini dikarenakan pendidikan berkaitan erat dengan transformasi sosial bagaimana masyarakat ditata, disusun, diselenggarakan dan ditumbuhkembangkan. ${ }^{8}$ Agar tingkat kepercayaan masyarakat, sebagai stakeholder pendidikan, terhadap mutu lulusan sebuah perguruan tinggi terjaga dengan baik, dibutuhkan sebuah program pengembangan SDM dengan tujuan utama membentuk mental dan kompetensi mahasiswa yang berkualitas dan berdaya saing.

Keberhasilan pendidikan tinggi merupakan aspek relevansi. Karena aspek relevansi ini, perguruan tinggi dituntut mampu menghasilkan alumni yang memiliki daya saing dan siap berkiprah dalam pembangunan sesuai dengan bidang keahlian masing-masing yang dikuasainya. Relevansi pendidikan alumni ini ditunjukkan melalui profil pekerjaan (macam dan tempat pekerjaan),

${ }^{8}$ Zainuddin Maliki, Sosiologi Pendidikan, cet. II, Yogyakarta: UGM Press, 2010, hlm 173174. 
relevansi pekerjaan dengan latar belakang pendidikan, manfaat mata kuliah yang diprogram dalam pekerjaan, saran alumni untuk perbaikan kompetensi alumni. Selain itu, relevansi pendidikan juga ditunjukkan melalui pendapat pengguna alumni tentang kepuasan pengguna alumni. Meskipun usaha perguruan tinggi sedemikian rupa untuk menyiapkan alumninya agar terserap dalam dunia kerja, tetapi kenyataannya jumlah penganggur terdidik di Indonesia setiap tahun jumlahnya terus bertambah, seiring dengan dihasilkannya alumni, baik sarjana maupun diploma baru dari berbagai perguruan tinggi (PT). Jumlahnya tidak hanya berkisar pada angka ribuan, bahkan sampai ratusan ribu.

Fenomena semakin banyaknya pengangguran terdidik ini menjadi pekerjaan rumah pemerintah dan perguruan tinggi. Sebagai ujung tombak terdepan, perguruan tinggi khususnya program studi memiliki kewajiban dan tanggung jawab dalam menyiapkan alumninya agar mampu bersaing di dunia kerja. Untuk itu diperlukan berbagai upaya agar perguruan tinggi dapat mempersiapkan kebijakan yang memperkuat sistem pendidikan serta implementasinya agar perguruan tinggi pada tataran sistem, institusi, manajerial, dan teknis mampu membentuk SDM yang kreatif, inovatif, serta berkarakter, dapat bersaing dalam kancah global dan pada akhirnya mampu mengembangkan dirinya sehingga kualitas SDM meningkat. ${ }^{9}$ Perguruan tinggi yang memiliki mahasiswa berkualitas sudah barang tentu akan menghasilkan lulusan yang berkualitas pula.

Evaluasi di atas dapat dilakukan dengan berbagai langkah, salah satunya melalui upaya penelusuran terhadap alumni atau tracer study. Hampir setiap perguruan tinggi melakukan survey penelusuran alumni untuk memperoleh informasi tentang kekuatan, kelemahan, peluang, dan tantangan yang dihadapi alumni dalam dunia kerja. Kemudian hasil survey penelusuran alumni ini dapat digunakan sebagai dasar dalam menyusun kegiatan untuk perbaikan institusi di

9 Uhar Suharsaputra, Manajemen Pendidikan Perguruan Tinggi, Bandung: PT Refika Aditama, 2015, hlm. 5

77 MAGISTRA - Volume 10 Nomor 1 Juni 2019 
masa mendatang. Survey penelusuran alumni atau SPA merupakan pendekatan yang memungkinkan institusi pendidikan tinggi memperoleh informasi tentang kekurangan yang mungkin terjadi dalam proses pendidikan dan proses pembelajaran dan dapat merupakan dasar untuk perencanaan aktivitas untuk penyempurnaan di masa mendatang. Hal ini juga dilakukan oleh program studi PGMI Universitas Wahid Hasyim Semarang untuk merekam berapa banyak alumni setiap semester dan seterusnya. SPA merupakan kegiatan akademis yang perlu dan harus dilaksanakan oleh Perguruan Tinggi agar mampu memperoleh umpan balik (feedback) dari para lulusan tentang relevansi proses pendidikan yang telah dijalani dengan kemampuan meningkatkan taraf hidup lulusan di masyarakat. Tracer Study juga merupakan alat untuk memperoleh data yang dibutuhkan bagi pengembangan suatu perguruan tinggi.

Hasil SPA ini dapat digunakan untuk mengetahui keberhasilan proses pendidikan yang telah dilakukan terhadap keterserapan alumni dari segi keberhasilan mencapai pekerjaan baik yang sesuai atau tidak sesuai, lama masa tunggu dan kepuasan pengguna terhadap alumni program studi PGMI. Dengan kegiatan Tracer Study ini diharapkan lembaga pendidikan mendapatkan informasi kekurangan pelaksanaan program studi dan menyediakan dasar-dasar dalam pelaksanaan perencanaan di masa depan. Untuk itu informasi keberhasilan profesionalisme (karier, status, pendapatan) para alumni dibutuhkan. Demikian pula informasi terhadap pengetahuan dan keahlian yang relevan (hubungan antara pengetahuan dan keahlian dengan kebutuhan kerja, ruang lingkup pekerjaan, posisi professional). Informasi ini juga untuk melihat tingkat kepuasan masyarakat terhadap alumni program studi setelah mereka terjun di dunia kerja. Data ini sangat berguna sebagai bahan evaluasi program studi sekaligus pengambilan langkah strategis dalam upaya peningkatan mutu lulusan program studi PGMI FAI Universitas Wahid Hasyim Semarang. Inilah yang melandasi penelitian ini untuk mengetahui keterserapan alumni program studi PGMI dalam dunia kerja antara tahun 2015-2017. 


\section{B. METODE PENELITIAN}

Penelitian ini merupakan penelitian lapangan (field research), adapun permasalahan yang hendak dijawab dalam penelitian ini menggunakan pendekatan survey dan studi dokumentasi. ${ }^{10}$ Metode survey merupakan kegiatan penelitian yang mengumpulkan data pada saat tertentu dengan tujuan mendapatkan data-data di lapangan yang berhubungan dengan alumni, pengguna, dan tingkst kepuasan masyarakat pengguna terhadap alumni PGMI. Alur kerja survey penelusuran alumni sebagai berikut:

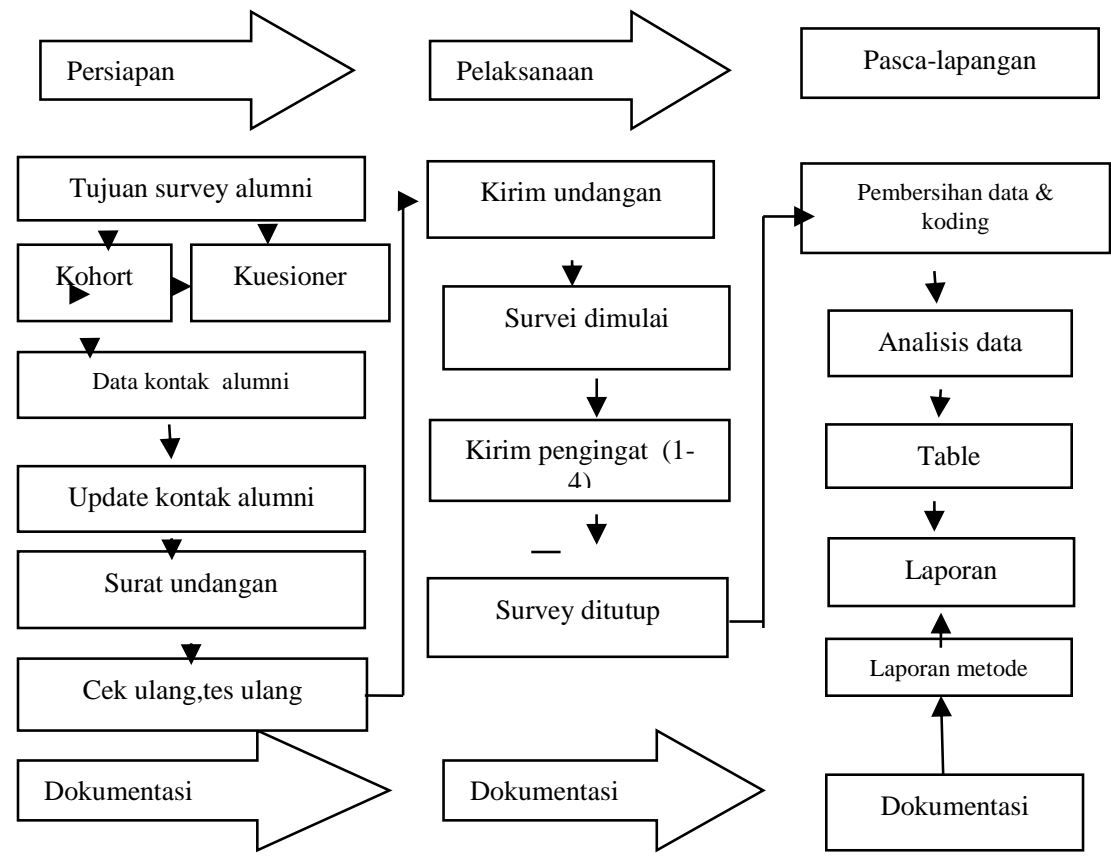

Gambar 1. Langkah SPA

Penelitian ini akan memfokuskan pada variabel penelitian profil alumni dan respon pengguna alumni. Profil alumni yang dimaksud meliputi: 1) jenis pekerjaan alumni, 2) masa tunggu lulusan, 3) persentase lulusan yang sudah bekerja dan yang belum bekerja. Sedangkan respon pengguna alumni (stakeholders) meliputi: kepuasaan pengguna alumni terhadap kinerja alumni

${ }^{10}$ yaitu cara pengumpulan data dari sejumlah unit atau individu dalam waktu yang bersamaan. Pendekatan ini bertujuan untuk mengetahui pendapat umum tentang suatu hal Suharsimi Arikunto, Prosedur Penelitian: Suatu Pendekatan Praktik, Jakarta: Rineka Cipta, 1992, hlm 84. 
dan kompetensi alumni yang diharapkan. Populasi adalah keseluruhan subyek atau kumpulan individu yang akan diteliti. Sampel adalah bagian-bagian dari keseluruhan individu yang menjadi objek dari penelitian.

Dalam riset ini, populasinya meliputi seluruh alumni Program Studi Pendidikan Guru Madrasah Ibtidaiyah Fakultas Agama Islam Universitas Wahid Hasyim Semarang yang lulus dari tahun 2015 sampai 2017. Adapun jumlah populasi alumni PGMI lulusan tahun 2015 - 2017 sebanyak 112 orang alumni. Berdasarkan jumlah populasi yang ada, maka sampel yang digunakan dalam penelitian diambil 100 responden dari populasi. Dari jumlah sampel yang ada, kemudian dibagi berdasarkan tahun kelulusan yaitu tahun 2015 sebanyak 32 mahasiswa, angkatan 2016 sebesar 43 mahasiswa, dan angkatan 2017 sejumlah 37 mahasiswa, total berjumlah 112 mahasiswa alumni. Dari jumlah 100 alumni yang dijadikan respon, dipilih responden secara acak tanpa memperhatikan jenis kelamin, tempat tinggal, maupun IPK. Responden yang terpilih pengambilan samplenya murni dengan random sampling.

Sumber data dalam penelitian ini adalah angket yang berisi pertanyaan terbuka dan tertutup dan disebar kepada responden, yaitu alumni PGMI FAI Universitas Wahid Hasyim Semarang. Pemilihan angket sebagai sumber data didasarkan pertimbangan efisiensi, di mana peneliti dapat menjangkau responden dalam jumlah besar meskipun berada di tempat yaang jauh. Selain itu responden dapat lebih leluasa dalam menuliskan keadaan yang sesungguhnya serta administrasinya lebih mudah.

Tehnik pengumpulan data yang digunakan oleh peneliti yakni studi dokumentasi dan wawancara.

1. Dokumentasi

Metode dokumentasi ini digunakan untuk mengumpulkan data tentang distribusi alumni program studi PGMI FAI Universitas Wahid Hasyim Semarang. Dokumen merupakan catatan peristiwa lampau. Dokumen bisa 
berbentuk tulisan, gambar atau karya-karya monumental dari seseorang. Studi dokumen merupakan pelengkap dari penggunaan metode observasi dan wawancara dalam penelitian kualitatif. ${ }^{11}$

2. Wawancara

Metode Wawancara (interview); yaitu metode pengumpulan data dengan cara mengadakan wawancara dengan responden dan pihak-pihak lain yang terkait dengan masalah yang diteliti. interview adalah pertemuan dua orang untuk bertukar informasi dan ide melalui tanya jawab, sehingga dapat dikonstruksikan makna dalam suatu topik tertentu. Ciri utama dari interview adalah adanya kontak langsung dengan cara tatap muka antara pencari informasi (interviewer) dan sumber informasi (interviewee). ${ }^{12}$ Untuk memperoleh informasi yang tepat dan objektif, setiap interviewer harus mampu menciptakan hubungan baik dengan interviewee. Dalam banyak hal, data hasil wawancara ini digunakan untuk melengkapi dan atau memperjelas data-data yang dikumpulkan melalui metode dokumentasi.

Analisis data dalam sebuah penelitian merupakan bagian yang sangat penting karena dengan analisis inilah data yang ada akan nampak manfaatnya terutama dalam memecahkan masalah penelitian dan mencapai tujuan akhir dalam penelitian. Setelah semua data terkumpul baik melalui dokumentasi dan wawancara, maka langkah selanjutnya adalah melakukan analisis data. Teknik analisis data dalam penelitian ini menggunakan analisis deskriptif untuk menganalisis hasil temuan data. Analisis deskriptif digunakan untuk melakukan perhitungan terhadap hasil dokumentasi, kemudian dari hasil perhitungan tersebut didekripsikan secara kuantitatif dari data dokumentasi dan secara kualitatif dari data interview. Analisis data ini menempuh tiga langkah yaitu reduksi data, display data, mengambil kesimpulan dan verifikasi. Secara visual proses analisis data dapat digambarkan berikut ini

\footnotetext{
${ }^{11}$ Sugiyono, Memahami Penelitian Kualitatif, Bandung: Alfabeta, 2005, hlm 82

${ }^{12}$ Sugiyono, Memahami ...., hlm 72
} 


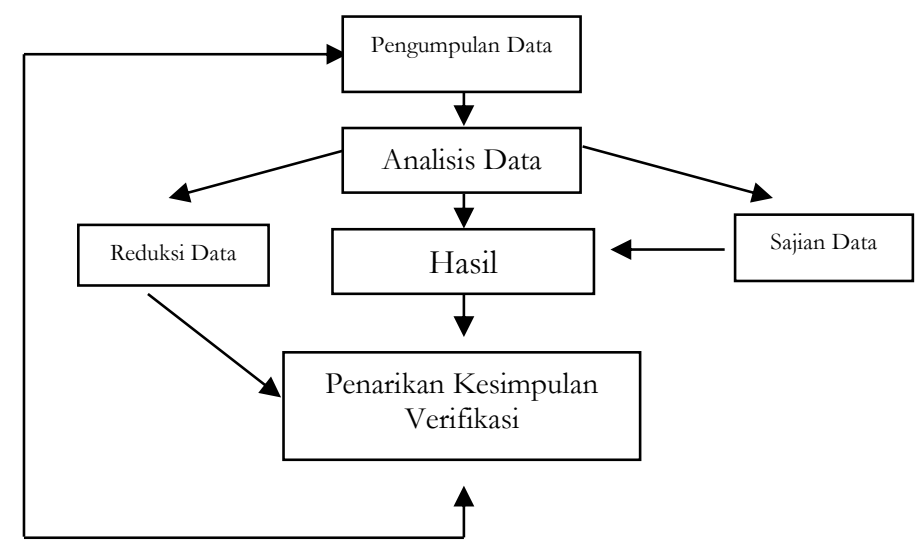

\section{Gambar 1 Langkah-langkah Teknik Analisis Data}

Langkah-langkah penelitian atau desain penelitian yang akan dilaksanakan adalah sebagai berikut:

1. Melaksanakan penelusuran terhadap semua alumni

2. Kuisioner diberikan kepada alumni dan stakeholders

3. Wawancara dilakukan terhadap alumni dan stakeholders

4. Menyusun data lapangan sebagai bahan laporan

5. Evaluasi dan refleksi

\section{HASIL DAN PEMBAHASAN}

Berdasarkan hasil penelitian, didapatkan jumlah populasi dalam penelitian ini, yakni alumni PGMI FAI Universitas Wahid Hasyim Semarang yang lulus tahun 2015-2017 berjumlah 112 orang alumni. Dari jumlah populasi tersebut kemudian diambil sample untuk menjadi responden responden sebanyak 65 orang alumni atau sekitar 59\% dari populasi. Para responden selanjutnya diberikan angket untuk diisi sesuai keadaannya. Berdasarkan angket yang dikirimkan kepada responden dan pengguna alumni, didapatkan data yang kemudian disajikan dalam bentuk tabel dan grafik.

Analisis data hasil penelitian yang dilakukan dalam penelitian ini ialah: profil alumni, meliputi jenis pekerjaan alumni, kesiapan bekerja, lama waktu tunggu 
pekerjaan, kontribusi soft skill dalam pekerjaan, dan evaluasi diri alumni. Untuk pengguna alumni, meliputi penilaian kepuasan pengguna alumni dan kompetensi yang dinilai memuaskan.

Berikut ini tabel jumlah populasi dan responden berdasarkan pada klasifikasi tahun lulusan:

Tabel 1 Persentase populasi dan responden

\begin{tabular}{|c|c|c|}
\hline Tahun lulus & Populasi & Responden \\
\hline $\mathbf{2 0 1 5}$ & 32 & 30 \\
\hline $\mathbf{2 0 1 6}$ & 43 & 35 \\
\hline $\mathbf{2 0 1 7}$ & 37 & 35 \\
\hline Jumlah & 112 & 100 \\
\hline
\end{tabular}

Dari 100 orang responden, jika diklasifikasikan bedasarkan jenis kelamin, maka data responden menunjukkan:

Tabel 2 Responden berdasarkan jenis kelamin

\begin{tabular}{|l|c|c|c|c|c|}
\hline $\begin{array}{c}\text { Jenis } \\
\text { kelamin }\end{array}$ & $\mathbf{2 0 1 5}$ & $\mathbf{2 0 1 6}$ & $\mathbf{2 0 1 7}$ & Jumlah & $\begin{array}{c}\text { \% dari } \\
\text { responden }\end{array}$ \\
\hline Laki-laki & 2 & 10 & 8 & 20 & 20 \\
\hline Perempuan & 28 & 25 & 27 & 80 & 80 \\
\hline Jumlah & 30 & 35 & 35 & 100 & 100 \\
\hline
\end{tabular}

Data tersebut memperlihatkan perbandingan responden laki-laki dan perempuan yang cukup signifikan perbedaannya. Responden perempuan mendominasi dengan 80 alumni atau $80 \%$ responden. Responden laki-laki hanya sebesar 20\% saja, yaitu sejumlah 20 alumni. Sesuai data yang ada, memang alumni PGMI FAI Universitas Wahid Hasyim Semarang lebih banyak didominasi perempuan dibandingkan laki-laki.

Berdasarkan lama studi alumni, dapat diketahui lama studi responden alumni PGMI FAI Universitas Wahid Hasyim Semarang. Data tersebut dapat dilihat dari tabel berikut: 
Tabel 3 Lama studi responden

\begin{tabular}{|c|c|c|}
\hline Lama Studi & Jumlah & \% \\
\hline 8 semester & 42 & 42 \\
\hline 9 semester & 39 & 39 \\
\hline 10 semester & 18 & 18 \\
\hline > 10 semester & 1 & 1 \\
\hline Jumlah & 100 & 100 \\
\hline
\end{tabular}

Tabel di atas menunjukkan bahwa lama studi alumni paling banyak yaitu 8 semester berjumlah 42 orang atau sebanyak $42 \%$. Sementara alumni yang lulus pada semester 9 sebanyak 39\% yaitu ada 39 orang, dan 18 alumni atau 18\% lulus pada semester 10. Hanya 1 responden yang lulus lebih dari 10 semester, dengan demikian dapat disimpulkan bahwa lama studi alumni sangat baik karena $81 \%$ responden lulus antara semester 8 dan semester 9 sehingga bisa dikatakan mayoritas alumni PGMI lulus dengan sangat baik. Hanya sebagian kecil saja yang lulus pada semester ke-10 atau yang lebih dari sepuluh semester.

\section{Profil Alumni PGMI}

Berdasarkan data yang terkumpul dari responden, diketahui informasi tentang jenis pekerjaan alumni setelah lulus dari kuliah. Jenis pekerjaan alumni antara lain guru MI dan SDIT, guru SD, guru PAUD/RA/TK, non guru, ada juga yang belum bekerja, dan melanjutkan studi strata 2. Beragamnya pekerjaan alumni menunjukkan bahwa lulusan PGMI tidak hanya menjadi guru, tetapi tertarik pada pekerjaan lain juga. Data pekerjaan alumni tersebut dapat dilihat pada tabel:

Tabel 4 Profil Alumni PGMI

\begin{tabular}{|c|c|c|c|c|}
\hline Tahun lulus & Guru & Non Guru & Belum/tidak kerja & Studi S2 \\
\hline $\mathbf{2 0 1 5}$ & 26 & 1 & 2 & 1 \\
\hline $\mathbf{2 0 1 6}$ & 30 & 2 & 0 & 3 \\
\hline $\mathbf{2 0 1 7}$ & 28 & 1 & 2 & 4 \\
\hline Jumlah & 84 & 4 & 4 & 8 \\
\hline
\end{tabular}


Diagram 1 Jenis pekerjaan alumni

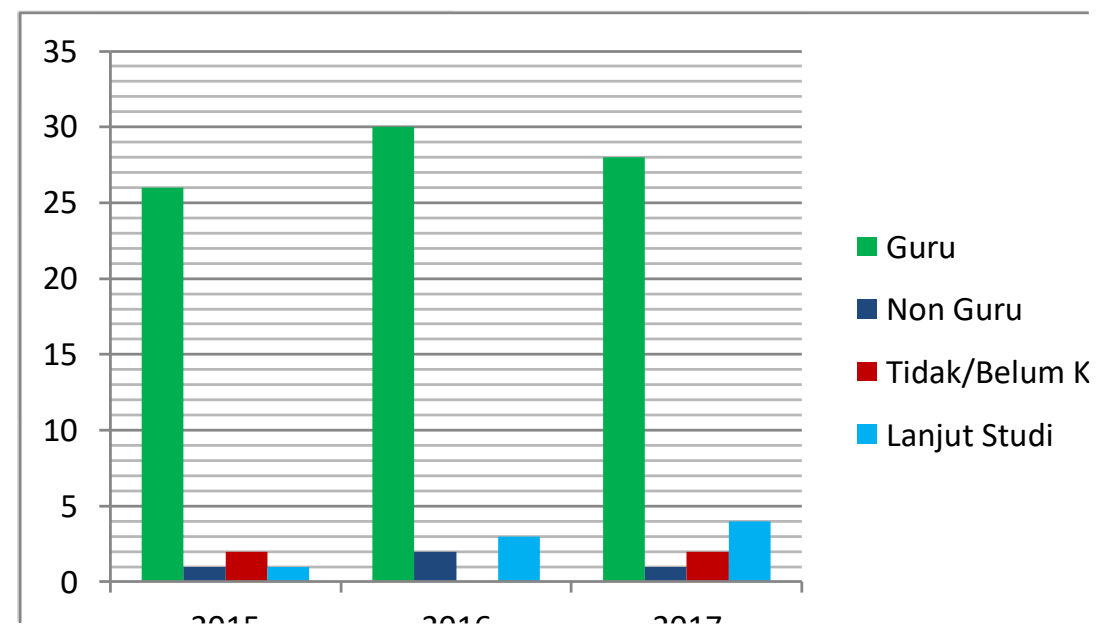

Tabel dan diagram tersebut menunjukkan bahwa setelah lulus, alumni PGMI banyak yang bekerja sebagai guru (sesuai kompetensi). Alumni yang bekerja sebagai guru mencapai jumlah 84 orang atau $84 \%$ responden. Adapun alumni yang bekerja pada sektor lain selain guru terdapat 4 responden, sedangkan 4 orang responden belum atau tidak bekerja. Sementara 8 orang responden atau $8 \%$ responden memilih meneruskan studi S2 dengan pilihan jurusan S2 PGMI di UIN Sunan Kalijaga Yogyakarta atau UIN Maliki Malang dan S2 Pendidikan Dasar UNNES Semarang. Dengan demikian responden yang sudah bekerja setelah lulus sebanyak 88 responden, 4 orang menjadi ibu rumah tangga, dan 8 lainnya melanjutkan studi ke jenjang S2. Alumni yang bekerja sebagai guru dapat diklasifikasikan berdasarkan lembaga yang diampu. Distribusi alumni yang bekerja sebagai guru dapat diklasifikasikan lebih rinci, yaitu:

Tabel. 5 Disribusi Pekerjaan Alumni sebagai Guru

\begin{tabular}{|l|c|c|}
\hline \multicolumn{1}{|c|}{ Pekerjaan } & Jumlah & \% GURU \\
\hline Guru MI/SDIT & 63 & 75 \\
\hline Guru SDN/SDS & 16 & 19 \\
\hline Guru TK/RA/PAUD & 5 & 6 \\
\hline Jumlah & 84 & 100 \\
\hline
\end{tabular}




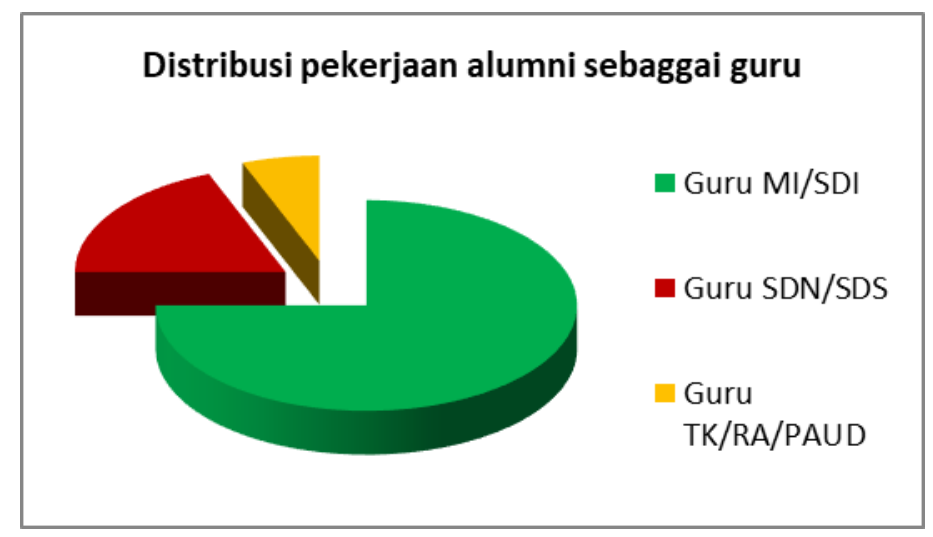

Hasil penelitian menunjukkan bahwa jenis pekerjaan alumni PGMI beragam, namun yang terbanyak yakni sebagai guru karena sesuai dengan kompetensi lulusan. Dari 84 responden yang bekerja sebagai guru, 63 orang atau $75 \%$ dari responden guru di antaranya bekerja sebagai guru MI dan SDIT, 16 orang atau 19\% sebagai guru SD, dan 5 orang atau $6 \%$ dari responden guru bekerja sebagai guru di jenjang TK/RA/PAUD. Hal ini membuktikan bahwa sebagian besar alumni PGMI bekerja sesuai kompetensinya yaitu guru kelas MI atau SDIT.

Kesiapan bekerja sesuai kompetensi. Setelah lulus dan sebelum bekerja, kesiapan diri dalam bekerja sesuai kompetensi sangat penting. Berdasarkan data yang ada, dapat dilihat bagaimana kesiapan alumni bekerja sesuai kompetensi:

Tabel. 6 Kesesuaian kompetensi dengan pekerjaan

\begin{tabular}{|c|c|c|}
\hline Kesesuaian kompetensi & Jumlah & $\%$ \\
\hline $\begin{array}{lll}\text { Sangat } & \text { sesuai } & \text { (Guru } \\
\text { MI/SDIT) } & & \\
\end{array}$ & 63 & 71.5 \\
\hline Sesuai (Guru SD/TK/PAUD) & 21 & 23.8 \\
\hline Tidak sesuai (pekerjaan lain) & 4 & 4.7 \\
\hline Jumlah & 88 & 100 \\
\hline
\end{tabular}

Persentase di atas menunjukkan bahwa alumni PGMI banyak yang mendapat pekerjaan sangat sesuai dengan bidangnya, yaitu guru kelas MI/SDIT, jumlahnya 63 responden atau $71.5 \%$ dari jumlah seluruh responden yang sudah bekerja. Data tersebut menunjukkan sebagian besar alumni PGMI bekerja sangat sesuai dengan kompetensi yang dihasilkan alumni. Sementara sebanyak 21 responden atau $23.8 \%$ 
bekerja sebagai guru SDN/SDS/ TK/RA/PAUD, pekerjaan ini juga masuk kategori sesuai karena alumni PGMI juga dibekali dengan ilmu yang berkaitan dengan pendidikan dan pengajaran anak. Hanya 4 responden yang bekerja tidak sesuai bidangnya, ada yang mengikuti program PSP3 Kemenpora, ada yang bekerja di bidang kontraktor, ada yang menjadi admin, dan satu lagi memilih berwirausaha.

Lama waktu tunggu mendapat pekerjaan. Lama waktu tunggu adalah waktu yang dibutuhkan alumni untuk memasuki dunia kerja. Masa tunggu kerja untuk mendapatkan pekerjaan pertama dihitung sejak tanggal lulus hingga tanggal sampai diterima pekerjaan di intitusi tertentu. Semakin pendek waktu tunggu untuk mendapatkan pekerjaan semakin baik pula kualitas alumni. Masa tunggu dalam penelitian ini dikategorikan dalam 5 bagian yaitu 0-3 bulan, 4-6 bulan, 7-9 bulan, 10-12 bulan dan lebih dari 1 tahun. Menurut dari Badan Akreditasi Nasional Perguruan Tinggi (BAN PT), masa tunggu yang baik adalah $<6$ bulan sejak lulus. Berikut data mengenai lama waktu tunggu alumni untuk memperoleh pekerjaan.

Tabel. 7 Lama Waktu Tunggu Alumni

\begin{tabular}{|c|c|c|}
\hline Waktu tunggu & Jumlah & $\%$ \\
\hline 0-3 bulan & 58 & 65.9 \\
\hline 4-6 bulan & 24 & 27.3 \\
\hline 7-9 bulan & 4 & 4.6 \\
\hline 10-12 bulan & 1 & 1.1 \\
\hline > 12 bulan & 1 & 1.1 \\
\hline Jumlah & 88 & 100 \\
\hline
\end{tabular}

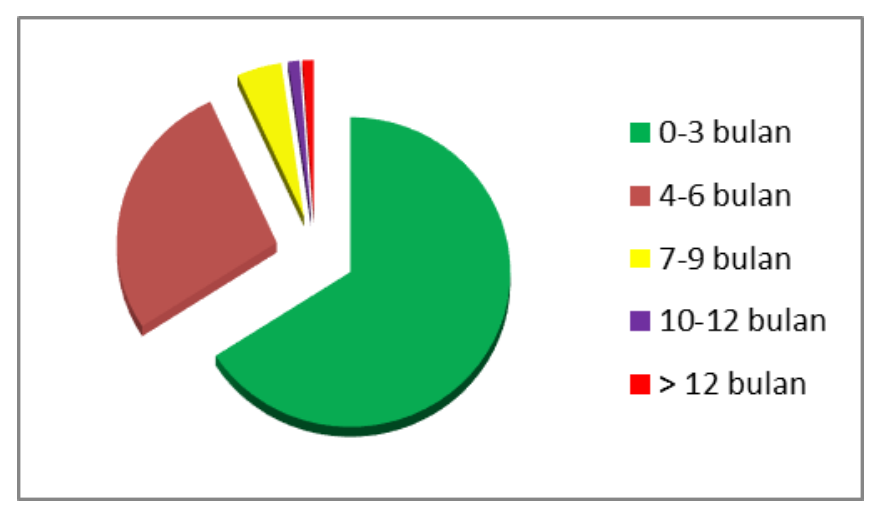

87 MAGISTRA - Volume 10 Nomor 1 Juni 2019 
Dari hasil penelitian memperlihatkan bahwa masa tunggu alumni 0-3 bulan sebanyak 58 responden atau $65.9 \%$ dari responden yang sudah bekerja. Sementara yang masa tunggunya 4-6 bulan berjumlah 24 responden atau $27.3 \%$ responden sudah bekerja. Alumni yang lama waktu tunggunya 7-9 bulan sebanyak 4 orang dan yang waktu tunggu 10-12 bulan berjumlah 1 orang responden, begitu pula hanya ada 1 responden yang lama waktu tunggunya di atas 12 bulan.

Data tersebut menunjukkan bahwa lulusan PGMI memiliki masa tunggu yang relatif baik, yakni di bawah 6 bulan bahkan 58 orang bekerja dengan masa tunggu di bawah 3 bulan. Hal ini dikarenakan para responden banyak yang sudah ikut membantu ekstra kurikuler seperti pramuka, seni, atau ekstra lain sehingga mereka sudah diminta ikut mengajar bahkan sebelum lulus. Maka tidak mengherankan apabila banyak alumni yang masa tunggunya di bawah 6 bulan sehingga masuk kategori baik menurut BAN PT.

\section{Kepuasan Masyarakat Pengguna Alumni PGMI}

Penilaian kepuasan pengguna alumni PGMI. Berdasarkan jumlah responden yang bekerja sebagai guru, baik guru MI, SDIT, SD, TK, RA, maupun PAUD, dinilai kinerjanya oleh atasan (Kepala Sekolah). Penilaian kinerja tersebut untuk melihat tingkat kepuasan pengguna terhadap kinerja alumni PGMI. Kinerja yang baik pasti aakan dinilai baik pula oleh atasan sehingga pengguna alumni merasa puas. Tingkat kepuasan pengguna dikategorikan dalam tiga tingkat,yaitu:

Tabel 8 Tingkat kepuasan pengguna alumni

\begin{tabular}{|l|c|c|}
\hline Tingkat kepuasan & Jumlah & $\%$ \\
\hline Puas & 67 & 79.7 \\
\hline Cukup Puas & 14 & 16.7 \\
\hline Kurang puas & 3 & 3.6 \\
\hline Jumlah & 84 & 100 \\
\hline
\end{tabular}




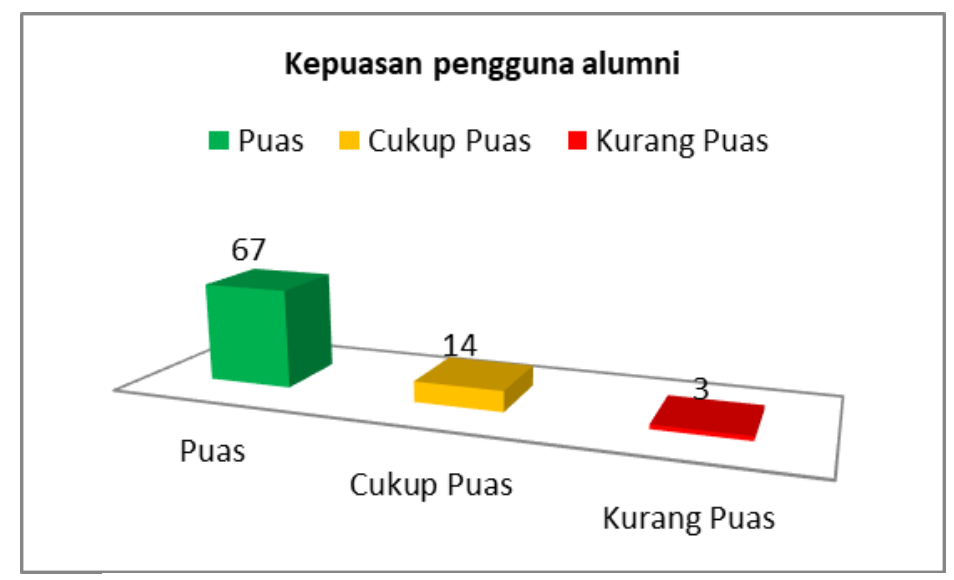

Data di atas menunjukkan bahwa kinerja alumni telah memuaskan atasannya, baik yang bekerja sebagai guru MI/SDIT, guru SDN/SDS, maupun yang menjadi guru TK/RA/PAUD. Terbukti dengan tingkat kepuasan yang mencapai angka 67 penguna atau 79.7\% masuk kategori puas dengan kinerja alumni PGMI. Sedangkan 14 orang pengguna atau $16.7 \%$ merasa cukup puas terhadap kinerja alumni, dan terdapat tiga pengguna atau $3.6 \%$ yang merasa kurang puas karena belum menunjukkan integritas, produktivitas dan kreativitas kerja yang tinggi.

Kompetensi alumni yang memuaskan. Dalam menyelesaikan pekerjaan, selain hardskill atau pengetahuan dan kemampuan akademik tentang pekerjaan tersebut, dibutuhkan softskill yakni keterampilan dan kompetensi lain yang menunjang kualitas diri alumni. Peran softskill terutama bagi guru MI sangat besar karena guru MI dituntut menjadi sosok yang terbaik dan memberikan pelayanan yang menyenangkan bagi anak didiknya sehingga pembelajaran dapat berjalan menarik. Tentu saja dengan tidak melupakan tujuan dari sebuah pembelajaran tersebut. Kontribusi softskill alumni dalam menyelesaikan pekerjaannya akan berimbas pada kepuasan pengguna alumni sebagai stakeholder PGMI FAI Universitas Wahid Hasyim Semarang.

Untuk menilai kompetensi alumni dalam bekerja yang dinilai memuaskan, dibuatlah beberapa kompetensi yang menunjang kinerja alumni. Kompetensi softskill tersebut terdiri dari 9 macam, yaitu integritas, profesionalisme, keluasan 
wawasan, kepemimpinan, kerjasama, bahasa asing, komunikasi, ICT, dan kreativitas. Masing-masing kompetensi dinilai berdasarkan kriteria Sangat Baik, Baik, dan Kurang Baik. Kompetensi alumni yang dinilai oleh pengguna alumni menunjukkan data sebagai berikut:

Tabel 9 Kompetensi Alumni yang Memuaskan Pengguna

\begin{tabular}{|l|c|c|c|c|}
\hline Kompetensi & $\begin{array}{c}\text { Sangat } \\
\text { Baik }\end{array}$ & Baik & $\begin{array}{c}\text { Kurang } \\
\text { Baik }\end{array}$ & Jumlah \\
\hline Integritas & 34 & 50 & 0 & 84 \\
\hline Profesionalisme & 2 & 82 & 0 & 84 \\
\hline $\begin{array}{l}\text { Keluasan } \\
\text { wawasan }\end{array}$ & 1 & 83 & 0 & 84 \\
\hline Kepemimpinan & 1 & 81 & 2 & 84 \\
\hline Kerjasama & 2 & 82 & 0 & 84 \\
\hline Bahasa Asing & 0 & 74 & 10 & 84 \\
\hline Komunikasi & 18 & 66 & 0 & 84 \\
\hline ICT & 1 & 80 & 3 & 84 \\
\hline Kreativitas & 2 & 82 & 0 & 84 \\
\hline
\end{tabular}

Dari data tersebut menunjukkan bahwa kompetensi yang masuk kategori sangat baik paling banyak (paling memuaskan) dari alumni yaitu integritas terkait moral dan tanggung jawab, di mana terdapat 34 pengguna alumni menilai integritas lulusan PGMI sangat baik, 50 pengguna menilai baik. tidak ada pengguna alumni yang menilai integritas lulusan dengan kurang baik. Sementara aspek kompetensi lain yang dinilai sangat baik yaitu komunikasi, di mana terdapat 18 orang pengguna alumni sangat puas dengan komunikasi alumni, 66 orang pengguna lulusan menilai baik dan tidak ada pengguna merasa kurang baik. Kompetensi lainnya seperti profesionalisme, ICT, keluasan wawasan, kerjasama, kepemimpinan, dan kreativitas rata-rata mendapat nilai baik. Nilai baik dari masing-masing kompetensi tersebut mencapai lebih dari 80 dari 84 pengguna alumni. Dengan demikian dapat dikatakan bahwa kompetensi penunjang yang dimiliki alumni PGMI sudah masuk kategori baik. 
Dari sembilan kompetensi yang menjadi pendukung kinerja alumni, terdapat satu kompetensi yang mendapat nilai kurang baik, yaitu kompetensi bahasa asing. Dari 84 pengguna alumni, hanya 74 pengguna menilai baik, sementara 10 pengguna menilai kemampuan berbahasa asing -baik bahasa Arab maupun Inggris- alumni dengan nilai kurang baik. Hal ini menjadi evaluasi bersama bagaimana caranya meningkatkan kemampuan berbahasa asing lulusan PGMI FAI Universitas Wahid Hasyim Semarang. Mengingat kemampuan berbahasa asing sangat diperlukan, maka data ini harus menjadi perhatian serius dari pengelola Prodi PGMI FAI Universitas Wahid Hasyim Semarang.

Hasil penelitian menunjukkan bahwa populasi dari alumni PGMI FAI Universitas Wahid Hasyim Semarang yang lulus tahun 2015 - 2017 adalah 112 alumni. Dari jumlah tersebut, alumni yang dijadikan responden sebanyak 100 orang dengan rincian: 30 responden merupakan lulusan tahun 2015, 35 responden lulusan tahun 2016, dan 35 responden adalah lulusan tahun 2017. Jika dilihat dari jenis kelamin responden, responden perempuan sangat mendominasi dengan jumlah 80 responden, sementara responden laki-laki hanya berjumlah 20 orang.

Dari 100 responden, ditemukan data bahwa lama studi alumni lulusan 20152017 terbanyak adalah lulus dalam waktu 8 semester (tepat 4 tahun) yakni 42 responden. Sementara alumni yang menempuh waktu 9 semester untuk lulus berjumlah 39 responden. Data ini menunjukkan bahwa lulusan PGMI lulus sesuai standar yaitu 8-9 semester. Capaian ini sangat baik sehingga tidak banyak mahasiswa yang terlalu lama kuliah. Dari data yang ada, terdapat 18 responden yang lulus pada semester ke-10, dan hanya ada satu orang responden yang lulus pada semester ke-12.

Selain lama studi yang tergolong baik, masa tunggu mendapatkan pekerjaan setelah lulus juga sangat baik. Sebanyak 82 responden dari 88 responden yang bekerja mendapatkan pekerjaan di bawah 6 bulan setelah lulus. Bahkan terdapat pula yang sudah ikut mengajar sebelum lulus kuliah. Responden yang sudah 
bekerja mayoritas sesuai dengan kompetensinya, yaitu menjadi guru kelas MI atau SDI, guru SDN/SDS, serta guru TK/RA/PAUD, yakni sebanyak 84 responden. Sedangkan 4 responden bekerja tidak sesuai kompetensi, 4 responden menikah dan menjadi ibu rumah tangga, dan 8 responden mimilih melanjutkan studi S2 dengan jurusan PGMI atau pendidikan dasar.

Data ini bernilai positif karena selain banyaknya alumni yang terserap sesuai kompetensinya menjadi guru, semakin banyak pula alumni yang melanjutkan studi S2 sehingga bisa semakin meningkatkan kualitas pendidikan dasar. Para alumni yang melanjutkan studi lanjut S2 diharapkan mampu menjadi praktisi dan konseptor pendidikan dasar Islam pada masa mendatang. Kemampuan akademik yang dimilikinya menjadi modal berharga dalam mencapai tujuan pendidikan serta meningkatkan kualitas pendidikan, khususnya kualitas pendidikan MI.

Salah satu tujuan utama dari program studi PGMI ialah mencetak guru MI yang berkualitas. Hasil penelitian menunjukkan bahwa 84\% lulusan PGMI bekerja sebagai guru. Dari 84 responden yang menjadi guru, didapatkan data kepuasan pengguna dalam hal ini atasan, baik kepala sekolah, waka, atau yang lain- yang cukup tinggi. Sebanyak 67 orang pengguna merasa puas dengan kinerja alumni, angka ini hampir $80 \%$ dari responden guru.

Sementara itu, pengguna yang merasa cukup puas berjumlah 14 orang, dan terdapat 3 orang pengguna alumni yang merasa kurang puas dengan kinerja lulusan PGMI. Kekurangpuasan pengguna ini patut menjadi perhatian serius dari pengelola program studi PGMI untuk terus meningkatkan kompetensi lulusannya. Peningkatan kualitas lulusan dengan berbagai langkah strategis harus selalu dilakukan agar lulusan yang terjun ke masyarakat memiliki kemampuan yang baik dalam bersosialisasi. Sebagai lembaga pendidikan yang menawarkan jasa alumni, program studi PGMI harus terus berbenah sesuai kebutuhan masyarakat dan perubahan sosial. 
Kepuasan pengguna alumni berdasarkan pada penilaian terhadap beberapa komponen kompetensi. Beberapa kompetensi alumni yang dinilai oleh pengguna lulusan, yaitu integritas, profesionalisme, keluasan wawasan, kepemimpinan, kerjasama, bahasa asing, komunikasi, ICT, dan kreativitas. Pemilihan kompetensi tersebut setidaknya sudah representatif dengan kompetensi yang harus dimiliki oleh seorang guru profesional, yakni kompetensi pedagogik, profesional, sosial, dan personal.

Dari beberapa kompetensi tersebut, integritas alumni berupa kejujuran, sikap, dan tanggung jawab mendapat nilai yang sangat baik, yaitu sebanyak 34 pengguna menilai sangat baik. Kemudian kompetensi komunikasi juga tergolong sangat baik di mana 18 pengguna merasa lulusan PGMI sangat baik dalam berkomunikasi. Kompetensi yang lain rata-rata mendapat prediket baik, dan terdapat kompetensi yang dirasa kurang sehingga perlu perbaikan, yaitu kemampuan bahasa asing, baik Arab maupun Inggris.

Sebanyak 10 pengguna merasa kompetensi bahasa asing lulusan PGMI masih kuang baik sehingga perlu perbaikan. Menggingat era modern saat ini menuntut kemampuan berbahasa asing, maka pengelola prodi PGMI harus memperhatikan aspek ini dalam upaya memperbaiki kualitas lulusannya. Kemampuan berbahasa asing sangat diperlukan sebagai bagian dari peningkatan kualitas SDM sesuai kebutuhan zaman yang semakin modern sehingga tidak ada lagi sekat antar negara. Begitu pula dalam bidang pendidikan, program kerjasama antar lembaga pendidikan lokal dengan lembaga pendidikan negara lain semakin banyak, hal itu tentu saja membutuhkan SDM yang memiliki kemampuan berbahasa asing yang baik agar mampu berkomunikasi dengan lancar.

\section{SIMPULAN}

Program Studi S1 Pendidikan Guru Madrasah Ibtidaiyah (PGMI) merupakan program studi yang bertujuan menghasilkan guru kelas MI atau SDI yang kompeten 
dan profesional demi meningkatkan kualitas pendidikan dasar Islam. Tidak hanya di jenjang MI, lulusan PGMI juga diharapkan mampu mendidik dan mengajar di jenjang SD karena kompetensi yang dimiliki lulusan PGMI FAI Universitas Wahid Hasyim Semarang merupakan kompetensi yang kompleks, yakni lulusan yang kompeten sebagai guru kelas pendidikan dasar sekaligus memiliki kompetensi mengajar mata pelajaan rumpun PAI (Aqidah Akhlaq, Al-Quran Hadits, Fiqh, dan SKI). Maka dari itu penelusuran kinerja alumni PGMI di lapangan sangat penting dilakukan sebagai bahan evaluasi sekaligus upaya meningkatkan kualitas lulusan PGMI FAI Universitas Wahid Hasyim Semarang. Berdasarkan pemaparan pada bab-bab sebelumnya, dapat disimpulkan:

1. Pekerjaan alumni setelah lulus dari kuliah sebagian besar relevan dengan kompetensinya, yaitu guru. Sebanyak 84 responden bekerja sebagai guru, 4 bekerja di sektor lain, 4 responden menikah, dan 8 responden melanjutkan studi S2. Dengan demikian dapat disimpulkan bahwa alumni PGMI sangat siap bekerja dengan kompetensi yang dimilikinya.

2. Lulusan PGMI memiliki masa tunggu yang relatif baik, yakni di bawah 6 bulan, bahkan 58 responden bekerja dengan masa tunggu di bawah 3 bulan. Hal ini dikarenakan para responden banyak yang sudah ikut membantu ekstra kurikuler seperti pramuka, seni, atau ekstra lain sehingga mereka sudah diminta ikut mengajar bahkan sebelum lulus.

3. Alumni yang bekerja sebagai guru sangat puas karena telah bekerja sesuai dengan jenjang pendidikannya. Relevansi ini sangat berpengaruh dalam kinerja di lapangan, di mana mayoritas alumni bekerja dengan baik karena sudah dibekali kompetensi yang sesuai pekerjaan.

4. Dalam bekerja, tidak hanya hardskill saja yang dibutuhkan alumni, para alumni PGMI merasakan softskill yang didapat di berbagai organisasi dan pelatihan sangat membantu dalam menyelesaikan pekerjaan. Kontribusi ini sangat besar dalam meningkatkan produktivitas dan kreativitas pekerjaan. 
5. Pengguna lulusan PGMI, baik kepala sekolah/madrasah, wakil kepala, maupun atasan lainnya merasa puas dengan kinerja alumni PGMI. Hal ini terlihat dari 67 pengguna merasa puas dengan kinerja alumni, 14 pengguna merasa cukup puas, dan 3 pengguna yang merasa kurang puas.

Kompetensi lulusan yang sangat menunjang kinerja alumni dengan nilai sangat baik terbanyak adalah integritas yang berupa kejujuran, sikap, dan tanggung jawab alumni dalam bekerja. Kemudian komunikasi alumni juga dinilai sangat baik. Terdapat satu kompetensi yang banyak dinilai kurang, yaitu kemampuan berbahasa asing, sedangkan kompetensi lain seperti profesionalisme, keluasan wawasan, kerjasama, ICT, maupun kreativitas dinilai sudah baik oleh pengguna lulusan. 


\section{DAFTAR PUSTAKA}

Buku Panduan Akademik IAIN Walisongo, Semarang: IAIN Walisongo, 2014

Kurikulum 2013, Model Pemebelajaran di Sekolah Dasar dan Madrasah Ibtidaiyah menggunakan tematik terpadu, 2013

Maliki, Zainuddin, Sosiologi Pendidikan, cet. II, Yogyakarta: UGM Press, 2010

Nasution, Berbagai Pendekatan dalam Proses Belajar dan Mengajar, Jakarta: Bumi Aksara, 2003

Pasal 2 Peraturan Pemerintah Nomor 60 tahun tentang Perguruan Tinggi, 1999

Pasal 3 Peraturan Pemerintah Nomor 61 tahun 1999 tentang Penetapan Perguruan Tinggi Negeri

Potter, Booby de, Quantum Teaching, Birmingham: Routladge Press, 2000

Sugiyono, Memahami Penelitian Kualitatif, Bandung: Alfabeta, 2005

Suharsaputra, Uhar, Manajemen Pendidikan Perguruan Tinggi, Bandung: PT Refika Aditama, 2015

Sutrisno, Pendidikan Islam Yang Menghidupkan, Cet II Yogyakarta: Kota Kembang, 2008

Undang-undang Republik Indonesia Nomor 14 Tahun 2005 Tentang Guru dan Dosen, Jakarata: Depdiknas RI, 2006 